Tables annuelles de constantes et données numériques de chimie, physique, biologie et technologie (Annual Tables of Constants and Numerical Data; Chemical, Physical, Biological and Technological). Donnees numeriques sur l'effet Raman: spectres, intensites, modes de vibration (Numerical Data on the Raman Effect: Spectra, Intensities, Vibration Patterns). Par Dr. M. Magat. Annees: 1931 dे 1934. Pp. 112. (Paris: Gauthier-Villars; Now York: MeGraw-Hill Book Co., Inc., 1936.)

THIs is principally a collection of data obtained on the Raman effect between 1931 and 1934. The substances whose spectra are described are grouped. according to their chemical constitution, one fifth of the space being devoted to inorganic compounds and four fifths to organic compounds. In making the compilation, Dr. Magat has attempted to assess the relative reliability of the work of different authors where more than one investigation has been made of a particular substance, and, where necessary and possible, has given mean wave-numbers. He has also made an individual contribution of considerable value in making an attempt to correlate intensity data. It is a pity that so little attention is usually paid to accurate measurement of intensities when the original plates of the spectra are obtained. The methods of photographic photometry are not unduly difficult, and in the present case the technique is often simplified by the fact that the spectrum is comprised within a small wave-length range. There is little doubt that much of the work described here will have to be repeated ultimately on this account, when it becomes necessary to compare it with the rapidly developing theory of polyatomic molecules.

There is an appendix on the modes of vibration of polyatomic molecules, and two lists of papers-in addition to those in the text-one on the theory of the Raman effect and the other on some of its applications. The apparent completeness of the data, many of the sources being inaccessible to the ordinary worker, and the excellent way in which they are reproduced, combine to make the book indispensable for anyone interested in this field.

\section{The Making of Modern Turkey, from Byzantium to Angora}

By Sir Harry Luke. Pp. viii $+246+1$ plate. (London : Macmillan and Co., Ltd., 1936.) 10s. 6d. net.

SiR Harry LUKE's personal acquaintance with Turkey began so long ago as 1904, and at one point or another he has been in touch with the Turk ever since that date. In consequence he speaks with authority and understanding of the ideals and aspirations which inspired the political and social movements of the present century and have transformed Turkey from the titular seat of an international spiritual hegemony, as was claimed, into a nationalist State. His purpose is not to write a history of the Turks, but to analyse the forces and the elements which, partly rooted in Byzantium, partly arising out of the consequences of the conversion of the Turks to Islam, made the country in the end "the Sick Man of Europe", and in the inevitable disintegration of an international society, left nation. alism and a dictator as apparently the only way open to reform.

Sir Harry Luke's critical judgment places recent developments in Turkey in their true historical perspective, and his book is indispensable to anyone who seeks to understand the play of race, language and politics in modern Turkish social development.

\section{Handbuch der Vererbungswissenschaft}

Herausgegeben von E. Baur und M. Hartmann. Band 3: Genetik und Tierzuchtung. Von C. Kronacher. Pp. vii +280 . (Berlin: Gebruder Borntraeger, 1934.) 37.50 gold marks.

THIs handbook of animal breeding is a valuable summary of practical results in the improvement of domestic animals, including rabbits and some birds as well as horses, cattle, sheep, pigs and goats. Such questions as twinning in cattle are dealt with and two pairs of identical twins are described. Various interspecific crosses are discussed, as well as the inheritance of numerous abnormalities in all domestic breeds. The considerable amount of knowledge of serology in the different groups is also summarized. Emphasis is laid on the inheritance of qualities of practical value, such as milk yield in cows, wool characters and fertility in sheep. Such a summary should be of much value to all veterinarians and practical breeders. The book ends with a short index and a full bibliography occupying 87 pages.

\section{An Enquiry into Prognosis in the Neuroses}

By Dr. T. A. Ross. Pp. vii + 194. (Cambridge : At the University Press, 1936.) 10s. 6d. net.

THIs is an account of the results of treatment at the Cassel Hospital for Functional Nervous Disorders. The account covers twelve hundred patients. About 40 per cent of the patients reported themselves well at the end of three years, 34 per cent at the end of five years. We do not like to think that the nursing staff were meant to be neutral. An understanding nurse can do so much to help a patient; the doctor need not think he is a little tin god who gets all the patient's confidence. Nurses trained on psychological lines can be so understanding. The common. sense attitude adopted towards the much over-rated placebo, occupation therapy, is welcome.

\section{Heredity and the Ascent of Man}

By Dr. C. C. Hurst. Pp. ix + 138. (Cambridge : At the University Press, 1935.) 3s. 6d. net.

Dr. Hurst's little volume is less stereotyped and more discursive than the usual elementary book on this subject. His nine chapters begin with "The Mystery of Life" and the gene, ending on the experimental creation of new species, the ascent of man and the future of man and mind. The gene is regarded as the origin of life, and the evolution of man and his civilization are briefly traced. While highly speculative in places, yet Dr. Hurst succeods in bringing out many of the salient recent facts of genetics. 